\title{
INTEGRATION OF UNMANNED AERIAL VEHICLE DATA WITH GEOGRAPHICAL INFORMATION SYSTEMS
}

DOI: http://dx.doi.org/10.18509/GBP.2018.65

UDC: 528.931:004]:623.746.2-519 (560)

\author{
Tarık Türk \\ Anıl Can Birdal \\ Önder Gürsoy \\ Rutkay Atun \\ Cumhuriyet University, Faculty of Engineering, Department of Geomatics Engineering, Sivas, \\ Turkey
}

\begin{abstract}
Unmanned Aerial Vehicles (UAVs) are successfully used in many different fields such as military, forest fire, archaeological sites, agricultural applications, traffic control, radiation monitoring, natural disasters, urban management etc. At the same time, UAVs are extremely important tools for achieving accurate and up-to-date information quickly and economically. Today, UAVs can stay in the air for up to about 3.5 hours, and during this time they can take in aerial images that can produce ortho-images of an area of about 15 square kilometers. All of these features make UAV the tool of professional land surveying and ortho-image production that is fast, accurate and easy to use.

The most important basic component in Geographical Information Systems (GIS) is geographical data. UAVs which produces this data quickly and accurately, are one of the most important data collection methods. In recent years, it has been utilized effectively from the production of ortho-images used as basic data in GIS. In this study, the data obtained from the UAV at the study area of Cumhuriyet University Campus (Sivas city, Turkey) were evaluated with the photogrammetric data evaluation software Pix4D and the Digital Terrain Model (DTM) and ortho-images were produced. By interpreting these products, geographical layers such as buildings, electric poles, roads and manholes related to the campus were created on the GIS environment and the infrastructure of the Campus Information System (CIS) was established. Thus, a inquirable and analysable GIS-based system has been created to contribute to the management and planning activities to be carried out on the campus. As a result, UAV photogrammetry is a fast and easy to get economic geographical data for GIS-based studies, and is a tool for updating these systems in efficient times to provide effective and productive results and updates to information systems.
\end{abstract}

Keywords: Geographical Information Systems, Unmanned Aerial Vehicles, Campus Information System

\section{INTRODUCTION}

UAV systems developed so fast over the last decade, it is now placing classical photogrammetric and remote sensing methods efficiently. Not only they are used in strict applications, but also in a variety of fields like agricultural applications [15], surveillance missions [9], aerial monitoring [8], cultural heritage [11], cadastral [7] applications etc [19]. UAV systems have enabled easy, autonomous and low cost acquisition of aerial 
photos. Researchers have worked on reliability of these systems for over a decade. Now, still with some issues they are used in a variety of fields as a first hand data acquisition systems.

An UAV system usually consists of related payload, a ground control station for mission planning, real time navigation and communication link between station and vehicle [3]. They require no onboard pilot and can maintain a flight pattern above ground [12]. According to the size of the UAV, there are various launching methods like air, handheld, mechanical and autonomous. Technological improvements in Global Navigation Satellite Systems, digital cameras (pref. consumer digital camera types) allowed smaller UAV to be used in various applications. Eisenbess [5] and Blyenburgh [16] provided valuable reports about UAV classifications. Not only camera sensor are applied to UAV systems. There are also measurement devices like Light Detection and Ranging (LiDAR) scanners [14], Synthetic Aperture Radars (SAR) [10] that can be applied to UAV systems but due to their cost, weight and size, they remain challenging in most ways.

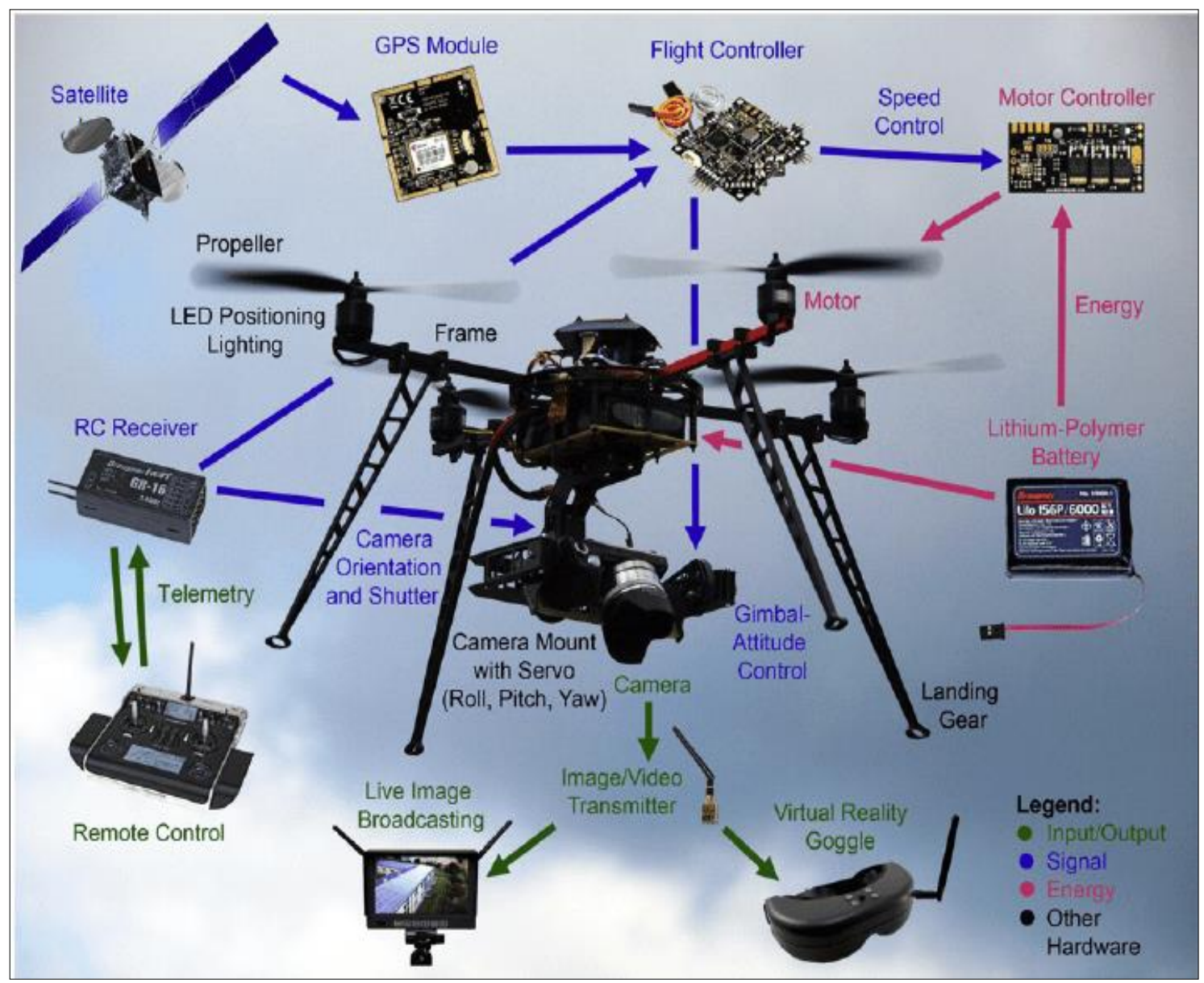

Figure 1. UAV Payload [17]

CIS of a university consists of geographical and non- geographical data of the study area. The main use of CIS is to store, query, analyze and present this data to the user with various formats (ie. Charts, reports, maps etc.) [2]. With the design of a CIS, personnel and facility management of a university and also creating plans for the future would be based on a real time based system that can be updated and analyzed at any time desired. There are a lot of previous works about CIS. Aydınoğlu \& Yomralığlu [2] and Kahraman 
et al. [6], published web based campus information systems in their studies. Asif \& Krogstie [1], created a campus-wide information mobile system that provides user-centric information to students.

In this study, it was aimed to create the infrastructure the CIS of Cumhuriyet University of Sivas Province, Turkey by integrating with GIS of data obtained from UAV. Thus, queries, spatial analyzes and documentations can be performed quickly and effectively on the CIS environment.

\section{MATERIALS AND METHODS}

The UAV flight mission consisted of 1170 images, also covered approx. 681 hectares. C Astral Bramor model UAV system was used in the study [18]. Nine Ground Control Points (GCPs) were used in georeferencing stage, Ground Sampling Distance (GSD) was set to $3.37 \mathrm{~cm}$ and a root mean square (RMS) error of $0.02 \mathrm{~m}$ for horizontal and $0.05 \mathrm{~m}$ for vertical was obtained. A detailed workflow of the study is given in Figure 2.

\section{Workflow}

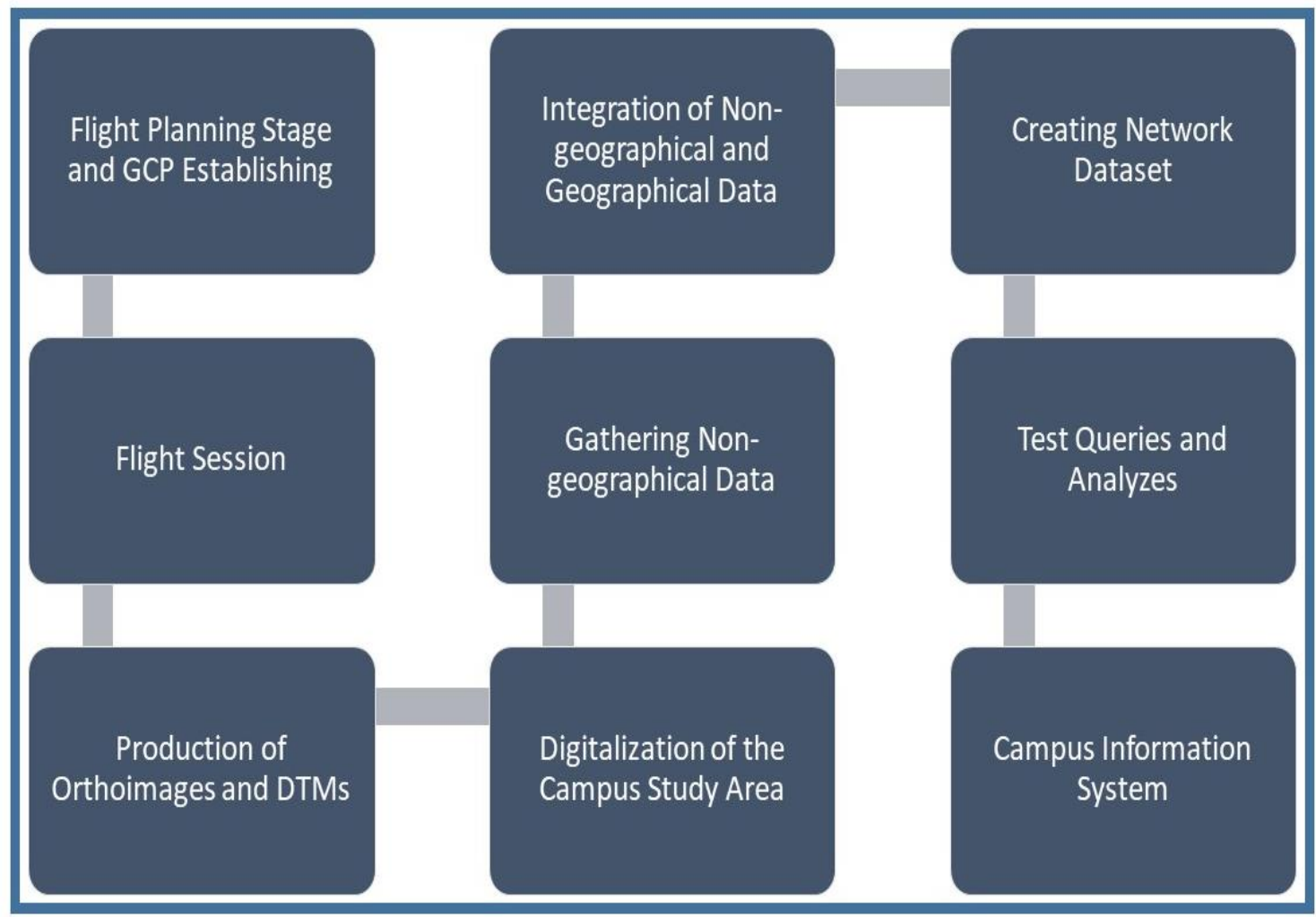

Figure 2. Study Workflow

Creating the infrastructure of CIS of the study area took around like 3 months. Flight session, GCP establishing and Production of Ortho-images and DTMs parts were completed in 15 days. Digitalization, non-geographical data gathering and the integration of geographical and non-geographical data stages were the most time consuming parts of the study, as it involves gathering data from administrative units, digitalization of the entire buildings with their room structures, roads etc., one-on-one integration between these data. 


\section{RESULTS AND DISCUSSION}

The ortho-image of the study area was produced via data obtained from UAV (Fig. 3).

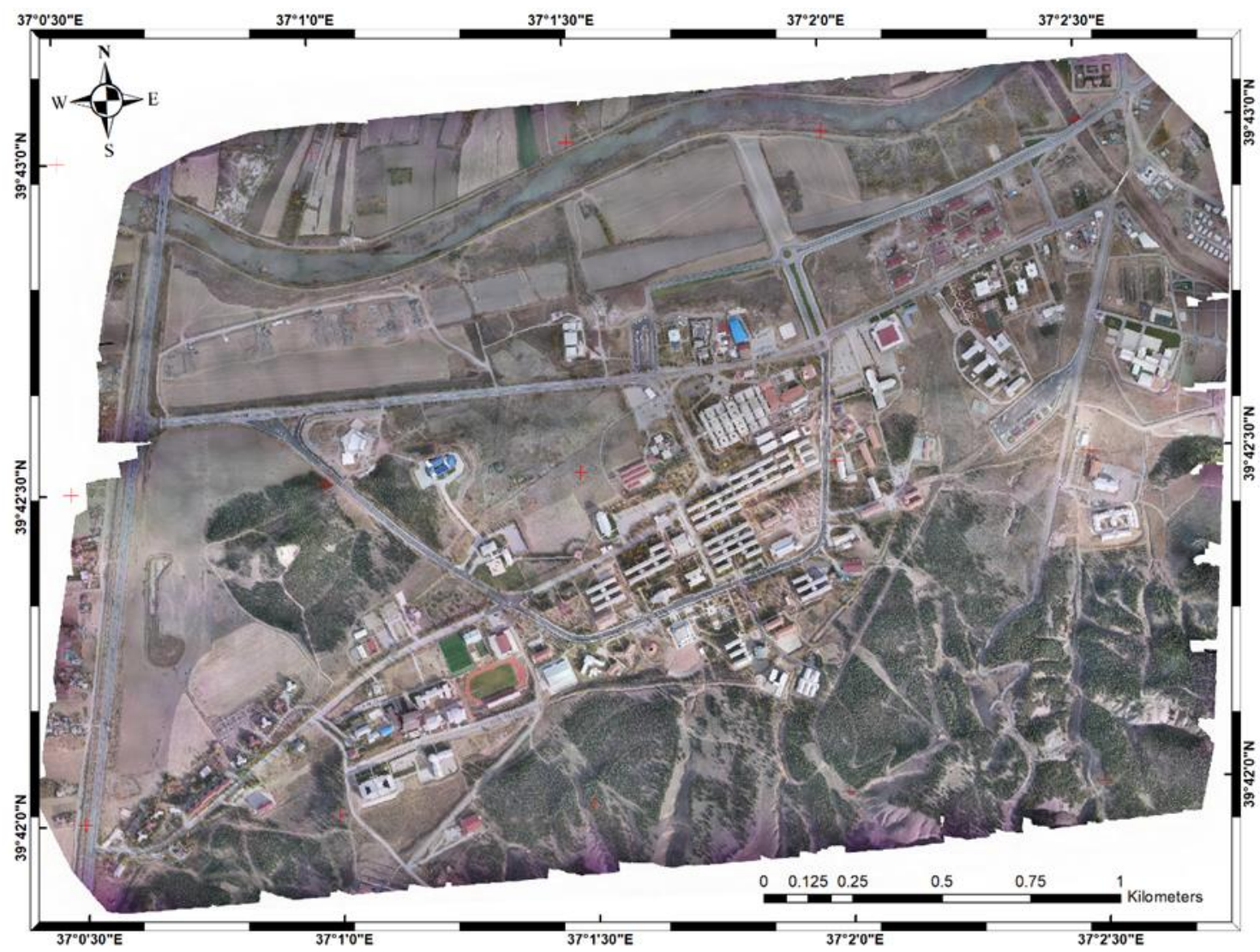

Figure 3. Orthoimage of the study area (Cumhuriyet University)

After processing stage of the raw images, digitalization process of the campus was performed. This process aims to create vector data of the campus area based on the orthoimages and DTM. Non-geographical data (ie. Personnel names, date of birth etc.) is then introduced to the CIS in order to make it available for queries and analyzes. This part is definitely the hardest part of this study. The UAV flight mission with its processing stage took about half a day. Digitalization of the campus, gathering administrative and educational data took months in order to be complete (Fig. 4 and Fig. 5). 


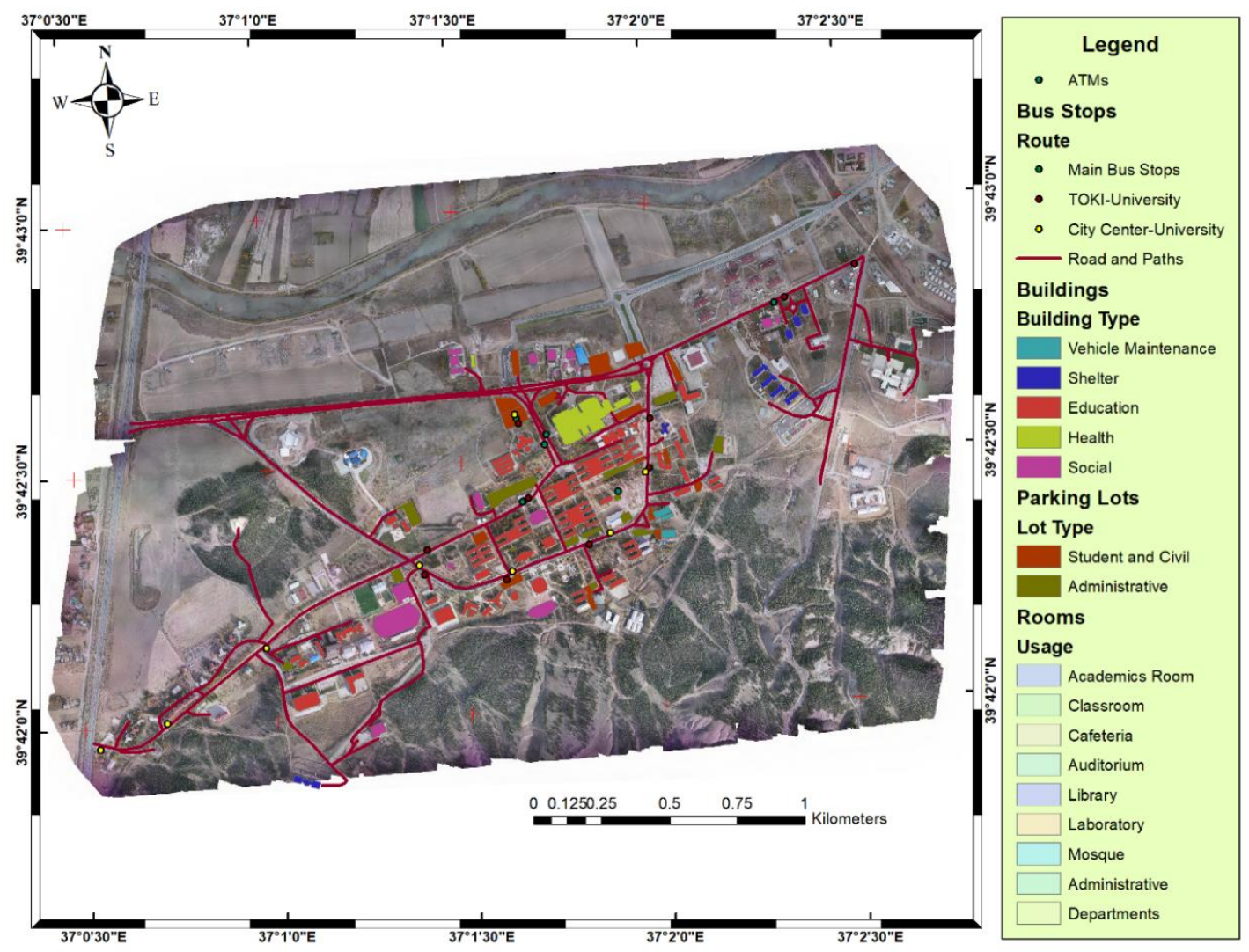

Figure 4. CIS infrastructure for Cumhuriyet University

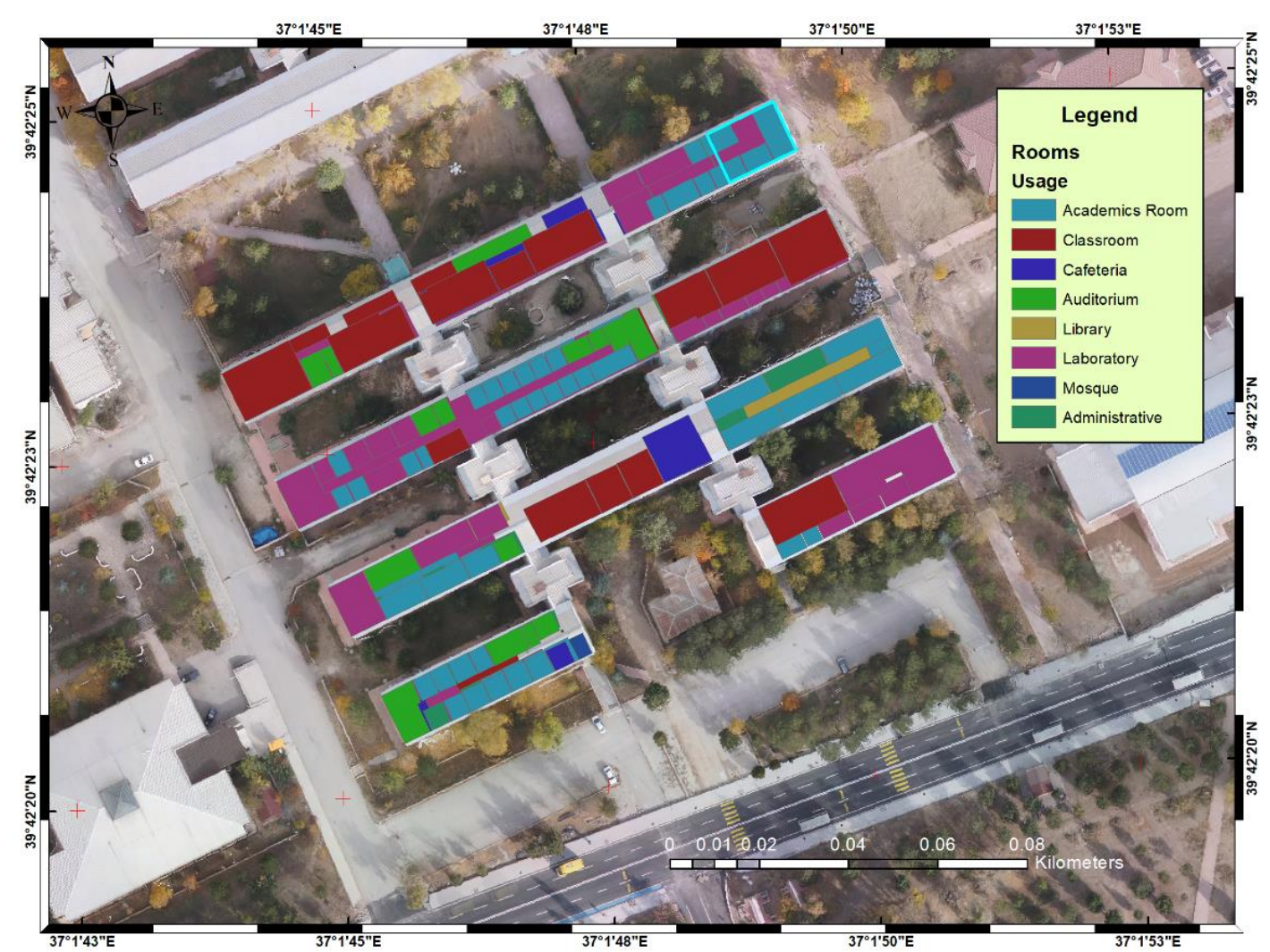

Figure 5. Detailed structure of a building 
Geographical data was digitalized from the ortho-image. Non-geographical data was prepared as tables in order to be put into geographical data to make the CIS ready for queries and analyzes. Some examples of tables can be seen in Fig. 6. Note that tables were prepared in Turkish language in order to be presented in the native language. Also, not all the fields but some examples' text data is presented in the Fig. 6.

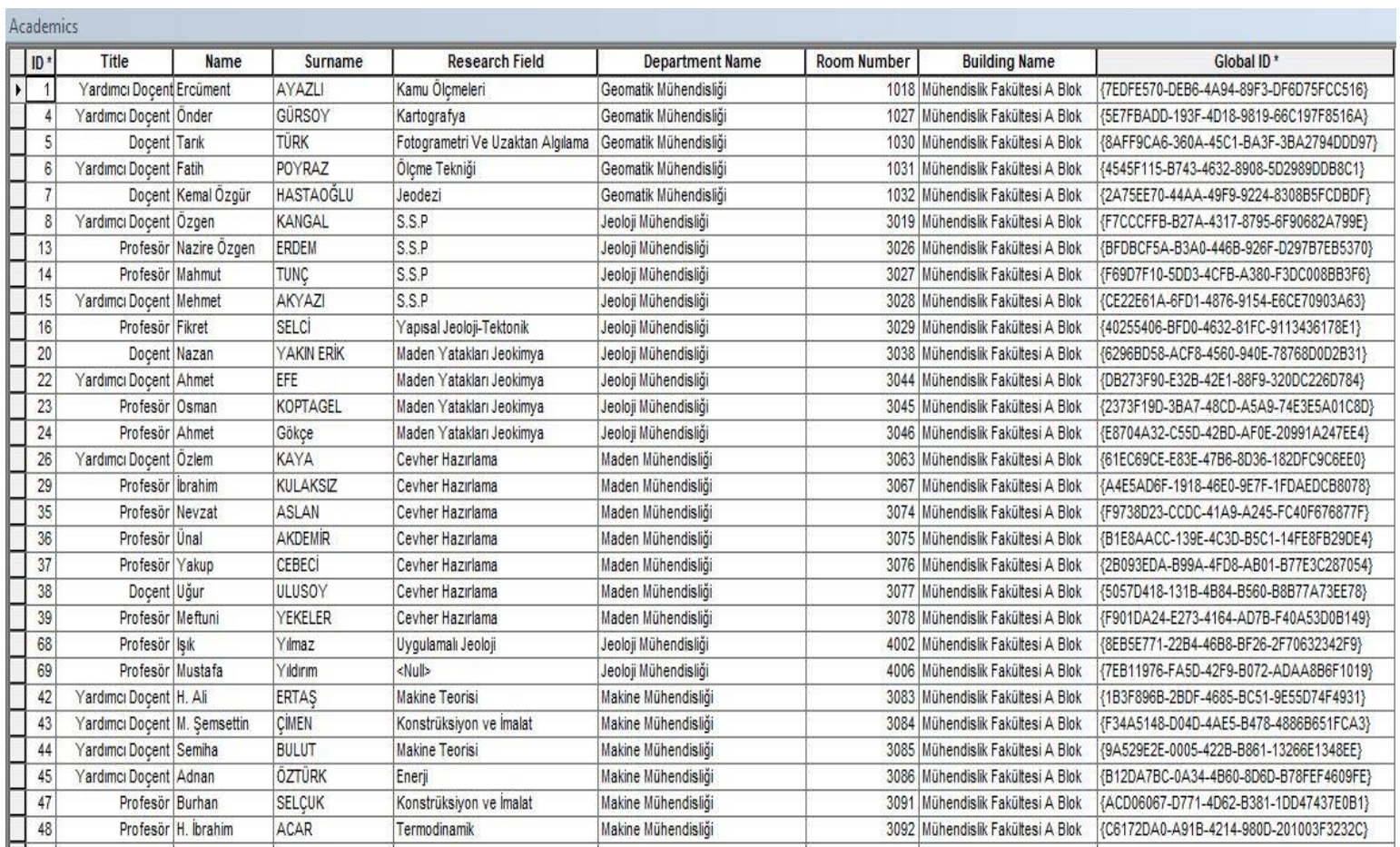

\begin{tabular}{|c|c|c|c|c|c|c|}
\hline \multicolumn{7}{|c|}{ Departments } \\
\hline ID: & Department Name & Building Name & Year of Establishment & Number of Students & Number of Academics & Global ID* \\
\hline 100 & Cerrahi Tip & Tip Faküttesi & 1974 & eNulls & 151 & $\{7 \mathrm{BC} 13 \mathrm{~A} 24-\mathrm{B} 688-4 \mathrm{E} 62-89 \mathrm{~B} 0-3 \mathrm{~A} 78 \mathrm{FB} 364 \mathrm{~B} 6 \mathrm{E}\}$ \\
\hline 101 & Dahili Tip & Tip Faküttesi & 1974 & eNulls & 215 & \{1AB9B41D-D593-4CFE-BB28-A4D53FD1D58E\} \\
\hline 277 & Tarih Bölümü & Edebiyat Faküttesi & 1978 & 583 & 12 & $\{34274068-E 9 E 5-4 A E D-B 0 F 2-5 C 7 F A 968 E 046\}$ \\
\hline 26 & Sosyoloji Bölümũ & Edebiyat Faküttesi & 1980 & 684 & 15 & \{E10EE311-B1BD-41E5-B431-D461192AC24F\} \\
\hline $19 \mathrm{~F}$ & Fransız Dili Ve Edebiyatı Bölümü & Edebiyat Faküttesi & 1982 & 41 & 4 & $\{9 E 5 E C A 03-3317-4 E 31-A 0 D 3-2 B 12298 C 26 A D\}$ \\
\hline 42 & Fizik Bölümü & Fen Faküttesi & 1983 & 65 & 13 & $\{$ D824AC73-BE06-4FA9-92D7-5B69CE521666\} \\
\hline 831 & Makine Mühendisliği & Mühendislik Faküttesi A Blok & 1984 & 948 & 18 & $\{F A 456 A D A-A 465-4 B 47-A 5 B F-045 E 43 D 3 D D 65\}$ \\
\hline 72 & Çevre Mühendisiğgi & Mühendislik Fakültesi B Blok & 1989 & 638 & 14 & \{C4B08B9D-3D18-48C2-8ABE-BB17DB41A05D\} \\
\hline $20 \mathrm{i}$ & ingiliz Dili Ve Edebiyatı Bölümũ & Edebiyat Faküttesi & 1990 & 293 & 10 & $\{150 \mathrm{ABOC} 3-50 \mathrm{DD}-4775-836 \mathrm{~B}-5480 \mathrm{BEF} 1368 \mathrm{~B}\}$ \\
\hline $81 \mathrm{H}$ & Kimya Mühendisiğği & Mühendislik Fakültesi B Blok & 1993 & 631 & 14 & $\{$ EOC95A26-45B2-47FB-9415-C71F4E6B9C5B\} \\
\hline 13 & Antropoloji Bölümü & Edebiyat Faküttesi & 1995 & 506 & 9 & $\{1 \mathrm{~A} 830513-59 B \mathrm{~B}-4 F 7 \mathrm{C}-92 \mathrm{~B} 4-1896 \mathrm{DgFF} 135 \mathrm{~B}\}$ \\
\hline 23 & Psikoloji Bölümũ & Edebiyat Faküttesi & 1995 & <Nulls & 5 & $\{1 \mathrm{~A} 0 \mathrm{~B} 3732-5 C 38-4 \mathrm{~A} 56-928 \mathrm{D}-7 \mathrm{E} 352 \mathrm{BD} 70814\}$ \\
\hline $47 \mathrm{t}$ & Heykel Bölümũ & Güzel Sanatlar Fakütesi Heykel Bölümū & 2001 & 34 & 7 & $\{56294$ DBC-2492-43CB-AC1E-AEE3C9F3096D $\}$ \\
\hline
\end{tabular}

Figure 6. Academician and Department tables

A network dataset is constructed based on the road geographical data in the CIS. An example of shortest car path to a desired point in CIS is presented in Fig. 7. Note that, the closest routes are solved between $1^{\text {st }}$ and $2^{\text {nd }}, 3^{\text {rd }}$ and $4^{\text {th }}$ points. 


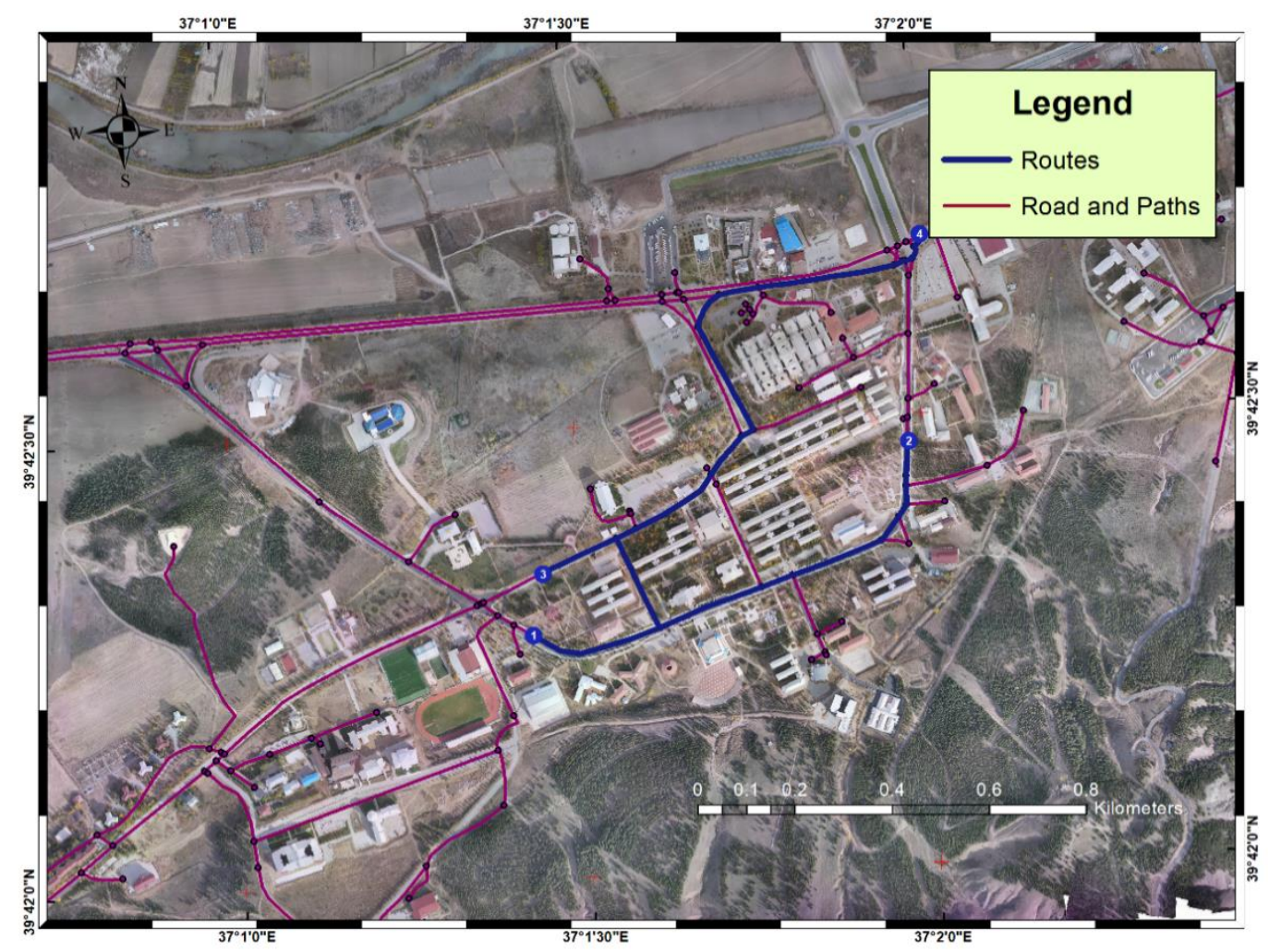

Figure 7. The closest route between $1^{\text {st }}$ and $2^{\text {nd }}, 3^{\text {rd }}$ and $4^{\text {th }}$ points

A handful of queries can be done in a CIS. By the help of "Selection" tab of ArcGIS software, every text-based data can be queried from geographical data located in the CIS. A small example of a room query is presented in Fig. 8.

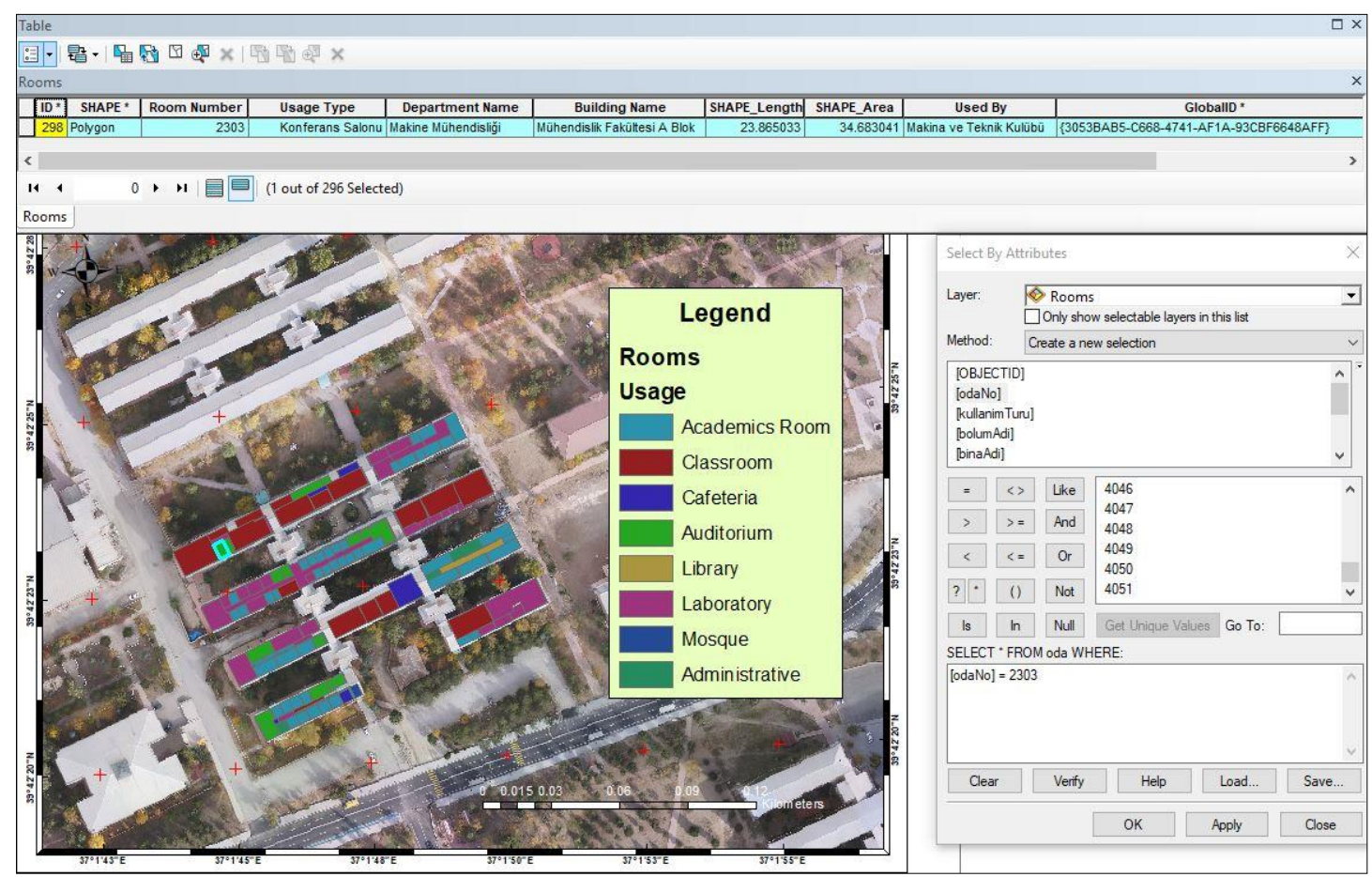

Figure 8. Room number queries with details 


\section{CONCLUSIONS}

If a CIS is supported by real time geographical and non-geographical information to be up-to-date, it can used to enhance the quality and integrity of administrative works, to select suitable locations for construction works (i.e. suitable location for a student residences/hostels in contrast to locate them closer to shopping places, educational buildings etc.), to create suitable road maps for a possible disaster evacuation scenario and etc.

Nowadays, it is not enough to create the infrastructure of CIS. It will be highly utilized for users in case CIS is published on the web or mobile environment. Up-to-date and accurate geographical data is too important for CIS studies. UAV is one of the most effective and indispensable tool in terms of obtaining geographical data. Consequently, it is reveal that UAV is one of the most remarkable geographical data collection methods for GIS-based studies.

\section{REFERENCES}

[1] Asif, M., \& Krogstie, J. Mobile student information system. Campus-Wide Information Systems, 28(1), 2011, 5-15.

[2] Aydınoğlu, A. Ç., \& Yomralığlu, T. Web based campus information system. In International Symposium On Geographic Information Systems GIS, 2002.

[3] Colomina I., Molina P. ISPRS Journal of Photogrammetry and Remote Sensing Unmanned aerial systems for photogrammetry and remote sensing: A review. ISPRS J Photogramm Remote Sens [Internet], 2014, 92:79-97. Available from:

http://dx.doi.org/10.1016/j.isprsjprs.2014.02.013

[4] DIY. DIY Drones website by Chris Anderson, 2013.

[5] Eisenbess H. UAV Photogrammetry. Ph.D. Thesis. Institut für Geodesie und Photogrammetrie, ETH-Zürich, 2009, Zürich, Switzerland.

[6] Kahraman, I., Karas, I. R., \& Rahman, A. A. Developing web-based 3D campus information system. ISG \& ISPRS, I(1), 2011, p1-2.

[7] Manyoky M., Theiler P., Steudler D., Eisenbeiss H. Unmanned aerial vehicle in cadastral applications. Int. Arch. Photogramm. Remote Sens. Spatial Inf. Sci. XXXVIII-1/C22, 2011, 5762.

[8] Merz T., Chapman S. Autonomous unmanned helicopter system for remote sensing missions in unknown environments. ISPRS, Int. Arch. Photogramm. Remote Sens. Spatial Inform. Sci. XXXVIII-1/C22, 2011, 277-282.

[9] Molina P., Pares M., Colomina I., Vitoria T., Silva P., Skaloud J., Kornus W., Prades R., Aguilera C. Drones to the Rescue! Unmanned aerial search missions based on thermal imaging and reliable navigation. InsideGNSS 7, 2012, 36-47.

[10] Remy M., de Macedo K., Moreira J. The first UAV-based P- and X-band Interferometric SAR system. IEEE, München, Germany, 2012, pp. 5041-5044.

[11] Rinaudo F., Chiabrando F., Lingua A., Spanò AT. Archaeological site monitoring: UAV photogrammetry can be an answer. In: INTERNATIONAL ARCHIVES OF THE PHOTOGRAMMETRY, REMOTE SENSING AND SPATIAL INFORMATION SCIENCES, vol. XXXIX n. B5, 2012, pp. 583-588. ISSN 1682,1750

[12] Ritter B. Use of Unmanned Aerial Vehicles (UAV) for Urban Tree Inventories. All theses. 2014, Paper 1890, Clemson University, South Carolina, USA. 
[13] Van Blyenburgh P. 2013-2014 RPAS Yearbook: Remotely Piloted Aircraft Systems: The Global Perspective 2013/2014. Technical Report. UVS International, 2013, Paris, France.

[14] Wallace, L.; Lucieer, A.; Watson, C.; Turner, D. Development of a UAV-LiDAR System with Application to Forest Inventory. Remote Sens., 4, 2012, 1519-1543.

[15] Zarco-Tejada PJ., González-Dugo V., Berni JAJ. Fluorescence, temperature and narrowband indices acquired from a UAV platform for water stress detection using a micro-hyperspectral imager and a thermal camera. Remote Sens Environ [Internet], 2012, 117:322-337. Available from: http://linkinghub.elsevier.com/retrieve/pii/S0034425711003555

[16] Van Blyenburgh P. 2013-2014 RPAS Yearbook: Remotely Piloted Aircraft Systems: The Global Perspective 2013/2014 (2013). Technical Report. UVS International. Paris, France.

[17] URL1:

https://i0.wp.com/www.mechlectures.com/wp-content/uploads/2017/06/Figure-2-The-maincomponents-of-the-developed-UAV-system-data-and-power-fl-ow.png? $\mathrm{w}=711 \&$ ssl $=1$

[18] URL 2: http://www.c-astral.com/en/products

[19] Birdal, Anıl Can. Determination of Tree Heights Using Unmanned Air Vehicles. Master of Science Thesis, 2016, Department of Remote Sensing and Geographical Information Systems, Anadolu University, Eskişehir, Turkey. 